\title{
Penerapan Pembelajaran Outdoor dengan Pendekatan Saintifik untuk Meningkatkan Hasil Belajar Siswa SMPN 6 Kota Bengkulu
}

\author{
Rahyuni $^{{ }^{*}}$, Zamzaili ${ }^{2}$, Aceng Ruyani ${ }^{1}$ \\ ${ }^{1}$ Pascasarjana Pendidikan IPA FKIP Universitas Bengkulu \\ ${ }^{2}$ Pascasarjana Pendidikan Matematika FKIP Universitas Bengkulu \\ *Email: rahyuni76@gmail.com
}

\begin{abstract}
[Implementation of outdoor learning with saintific approach to improve student learning of SMPN 6 Bengkulu City]. The aims of this study was to know the results of scientific learning (outdoor) and see the comparison the value of students's group who learn by using outdoor learning and groups of students who do not use outdoor learning. The subject of this research is the students of class VII SMPN6 Bengkulu City on academic year 2016/2017. The sample who taken are class VII G class control class VII $H$, experimental class, class VII E as a testing class. Sampling technique by purposive sampling. Instrument used double choice test instrument 25 problem,. The technique of data analysis using statistic Anova Mix (mixed Anova). Test normality by using test of covariance matrix. The average value of pretest of the experimental class students 62.1 after the average treatment of student postes increased to 86.25 which means an increase of 24.15. The control class Pretest and postes results Average score of pretest students 65,9 after conventional learning average student postes score increased to 75,5 which means an increase of 9.6. Student learning outcomes using outdoor learning method is higher than those not using the method, it is seen from the average experimental class value $(80,75)$ bigger than control class $(64,00)$ with increase of $26,37 \%$.
\end{abstract}

Keywords: Outdoor learning; saintific approach; student learning outcomes.

\begin{abstract}
ABSTRAK
Penelitian ini bertujuan untuk mengetahui hasil belajar saintifik (outdoor) dan melihat perbandingan nilai kelompok siswa yang belajar dengan menggunakan pembelajaran outdoor dan kelompok siswa yang tidak menggunakan pembelajaran outdoor. Subjek penelitian ini adalah siswa kelas VII SMPN6 Kota Bengkulu semester genap Tahun Akademik 2016/2017. Sampel yang diambil adalah kelas VII G kelas kontrol kelas VII H, kelas eksperimen, kelas VII E sebagai kelas pengujian. Teknik pengambilan sampel dengan purposive sampling. Instrumen yang digunakan instrumen tes pilihan ganda 25 masalah. Teknik analisis data menggunakan statistik Anova Mix (mixed Anova). Uji normalitas dengan menggunakan uji matriks kovariansi. Nilai rata-rata pretest dari siswa kelas eksperimen 62,1 setelah perlakuan rata-rata postingan siswa meningkat menjadi 86,25 yang berarti peningkatan 24,15. Pada kelas kontrol skor rata-rata pretest 65,9 setelah pembelajaran konvensional meningkat menjadi 75,5 yang berarti terdapat peningkatan skor sebesar 9,6. Hasil belajar siswa yang menggunakan metode outdoor learning lebih tinggi daripada yang tidak menggunakan metode ini. Hal ini dilihat dari rata-rata nilai kelas eksperimen $(80,75)$ lebih besar dari kelas kontrol $(64,00)$ dengan peningkatan sebesar $26,37 \%$.
\end{abstract}

Kata kunci: Pembelajaran outdoor; pendekatan santifik; hasil belajar siswa. 


\section{PENDAHULUAN}

Belajar adalah suatu usaha yang dilakukan oleh seseorang untuk memperoleh perubahan tingkah laku sebagai hasil interaksi dengan lingkungannya dalam memenuhi kebutuhannya. Belajar sebaik-baiknya adalah dengan menggunakan panca indra. IPA merupakan bagian dari sains. Sains mengandung makna pengajuan pertanyaan, pencarian jawaban, pemahaman jawaban, penyempurnaan jawaban baik tentang gejala maupun tentang karakteristik alam sekitar melalui cara-cara sistematis (Depdiknas, 2002).

Peraturan Pemerintah Pendidikan dan Kebudayaan (Permendikbud) nomor 81 A Tahun 2013 lampiran IV, proses pembelajaran terdiri atas lima kegiatan pengalaman belajar pokok yaitu: mengamati, menanya, mengumpulkan informasi / eksperimen, mengasosiasikan / mengolah informasi, dan mengkomunikasikan.

Salah satu masalah lingkungan hidup yang harus kita hadapi adalah masalah kelestarian alam (Mulyana, 2009). Alam mengalami eksplotasi, lebih oleh manusia untuk berbagai kebutuhan sehingga mengalami kerusakan. Kerusakan alam akibat perilaku manusia telah terjadi bertahuntahun, oleh karena itu perlu disiapkan generasi muda yang memahami dan mau serta mampu melakukan tindakan konservasi alam. Konservasi alam dilakukan khususnya bagi tumbuhan maupun hewan yang terancam keberadaannya (Astuti et al. 2017). Hal ini diperlukan demi kesejahteraan hidup manusia sendiri serta keturunan saat kini dan masa mendatang. Salah satu tugas kita adalah mempersiapkan generasi muda konservasionis (conservasionist) melalui pendidikan lingkungan hidup dengan kekhususan konservasi alam atau pendidikan konservasi alam, karena kita perlu merubah kebiasaan manusia yang merusak alam menjadi manusia yang memanfaatkan alam secara lestari.

Pada anak usia sekolah, pendidikan lingkungan harus memberikan aspek kognitif dan afektif sama baiknya dengan aspek psikomotor. Dalam pendidikan lingkungan, anak harus secara bertahap memperoleh pengalaman, pengetahuan, organisasi, disiplin dan kepercayaan diri melalui keterlibatan yang aktif dan efektif dengan dunia di sekitar mereka.

https://ejournal.unib.ac.id/index.php/pendipa
Pendidikan di sekolah sangat strategis sebagai tempat untuk merencanakan dan melaksanakan pendidikan lingkungan hidup bermuatan nilai-nilai, pengetahuan dan pembiasaan perilaku tertentu yang positif dalam rangka memberikan kesadaran tentang pentingnya sikap dan perilaku untuk melestarikan lingkungannya (Indonesia, 1990). Penggunaan media luar kelas (outdoor) menurut (Depdiknas, 2002) akan semakin mempermudah pemahaman anak tentang prinsip dan konsep serta contohcontoh yang mereka terima sebelumnya saat pengajaran di dalam ruang (indoor), selain itu juga dapat membangkitkan minat anak didik untuk menyelidiki dan menemukan sesuatu yang baru. Disamping itu, aktivitas di luar ruang kelas ini pun akan meningkatkan keterampilan psikomotor anak dalam melestarikan alam (Hastutiningsih et.al. 2016). Penelitian mengenai pembelajaran outdoor antara lain dilakukan oleh Linawati (2015) mengenai pengaruh outdoor study pada pembelajaran IPA SD, mengenai keefektifan pembelajaran outdoor berbasis nilai karakter (Saputra dan Novitasari, 2014), dan desain pembelajaran biologi dengan model jelajah alam oleh Alimah dan Susilo (2013).

Penelitian mengenai studi kandungan gizi Colocasia esculenta dan Colocasia gigantea sebagai pakan kura-kura Manoura emys di area Konservasi Kura-kura Universitas Bengkulu menggambarkan bagaimana kura-kura Baning (Manoura emys) yang merupakan kura-kura darat yang posturnya bisa besar, atau sering disebut Kura-kura Kaki Gajah. Keberadaan kura-kura ini sudah mulai langka akibat dari aktivitas manusia yang terus menerus menebang hutan untuk dijadikan lahan perkebunan kelapa sawit. Selain itu perlu disediakan pakan yang cocok untuk kelangsungan hidupnya di wilayah konservasi.

Penelitian ini kemudian diimplementasikan dalam pembelajaran konservasi sumber daya alam di sekolah. Sesuai dengan silabus pembelajaran IPA SMP Kelas VII semester II, materi tentang sumber daya alam dan upaya pelestariannya, mengajak siswa bagaimana melakukan konservasi terhadap hewan yang sudah langka, dan upaya apa saja yang harus dilakukan agar konservasi tersebut dapat menjadikan hewan konservasi menjadi bertahan. Maka peneliti melakukan 
penelitian untuk mengetahui hasil pembelajaran saintifik (outdoor) tentang konservasi hewan kura-kura terhadap pembelajaran di sekolah, melihat perbandingan nilai kelompok siswa yang belajar dengan menggunakan pembelajaran outdoor dan kelompok siswa yang tidak menggunakan pembelajaran outdoor.

\section{METODE PENEITIAN}

Subyek penelitian ini adalah siswa kelas VII SMPN6 Kota Bengkulu semester II tahun pelajaran 2016/2017. Jenis penelitian yang digunakan adalah penelitian eksperimen dengan metode outdor dengan pendekatan saintifik. Populasi dalam penelitian ini adalah siswa kelas VII yang terdiri dari 8 kelas dengan jumlah siswa 160 orang, sampel yang diambil adalah kelas VII G sebagai kelas kontrol kelas VII H sebagai kelas eksperimen kelas VII E sebagai kelas ujicoba. Teknik pengambilan sampel secara purposive sampling.

Instrumen yang digunakan dalam penelitian ini adalah instrument tes, untuk mengukur pengetahuan (kognitif) siswa dalam bentuk soal pilihan ganda. Instrumen yang telah diuji validitas yang berjumlah 25 soal. Teknik analisa data menggunakan statistik Anova Mix (Anova campuran) yang harus memenuhi syarat antara lain normalitas dan homogenitas. Uji normalitas dengan menggunakan uji matriks covarian.

\section{Desain penelitian}

Siswa diberikan pembelajaran sesuai RPP yaitu :

a. Pertemuan pertama, siswa diberikan materi tentang konservasi sumberdaya alam dan upaya pelestarianya melalui pembelajaran langsung, siswa diberikan pemahaman tentang apa itu konservasi, dan factor-faktor yang mempengaruhi kelangsungan konservasi,

b. Pertemuan kedua, melalui pembelajaran outdoor, siswa diajak pergi ke lokasi konservasi kura-kura Universitas Bengkulu, siswa berikan pengenalan terhadap kura-kura hewan konservasi, cara memberikan pakan, menimbang, bahkan cara mengukur faktor

https://ejournal.unib.ac.id/index.php/pendipa abiotik yang mendukung kegiatan konservasi.

c. Pertemuan ketiga, refleksi hasil kegiatan pada pertemuan kedua, dan melakukan evaluasi pembelajaran konservasi.

\section{HASIL DAN PEMBAHASAN}

Untuk mengetahui hasil belajar siswa maka dilakukan analisis dengan menggunakan Anova Mix (Anova campuran). Dinamakan Mixed Design (campuran) karena di dalamnya memadukan dua sub analisis yaitu :

a. Within Subject Test adalah pengujian perbedaan skor dalam satu kelompok (pre vs post)

b. Between Subject Test adalah pengujian perbedaan skor antar kelompok (eksperimen vs kontrol)

Data hasil belajar siswa

Tabel 1. Hasil Uji Coba Validitas Butir Soal

\begin{tabular}{|c|c|c|c|c|}
\hline No & $\mathbf{P}$ & $\mathbf{R}$ & D & Kriteria \\
\hline 1 & $\begin{array}{l}0.750 \\
0\end{array}$ & 0.475 & 0.6474 & dipakai \\
\hline 2 & $\begin{array}{l}0.600 \\
0 \\
\end{array}$ & 0.352 & 0.4463 & dipakai \\
\hline 3 & $\begin{array}{l}0.600 \\
0\end{array}$ & 0.432 & 0.5477 & dipakai \\
\hline 4 & $\begin{array}{l}0.550 \\
0\end{array}$ & 0.350 & 0.4406 & dipakai \\
\hline 5 & $\begin{array}{l}0.550 \\
0\end{array}$ & 0.567 & 0.7128 & dipakai \\
\hline 6 & $\begin{array}{l}0.550 \\
0 \\
\end{array}$ & 0.646 & 0.8118 & dipakai \\
\hline 7 & $\begin{array}{l}0.600 \\
0\end{array}$ & 0.492 & 0.6238 & dipakai \\
\hline 8 & $\begin{array}{l}0.650 \\
0\end{array}$ & 0.378 & 0.4867 & dipakai \\
\hline 9 & $\begin{array}{l}0.650 \\
0\end{array}$ & 0.481 & 0.6189 & dipakai \\
\hline 10 & $\begin{array}{l}0.250 \\
0\end{array}$ & 0.588 & 0.8015 & dipakai \\
\hline 11 & $\begin{array}{l}0.700 \\
0 \\
\end{array}$ & 0.539 & 0.7100 & dipakai \\
\hline 12 & $\begin{array}{l}0.450 \\
0 \\
\end{array}$ & 0.496 & 0.6237 & dipakai \\
\hline 13 & 0.700 & 0.368 & 0.4846 & dipakai \\
\hline
\end{tabular}




\begin{tabular}{|c|c|c|c|c|}
\hline & 0 & & & \\
\hline 14 & $\begin{array}{l}0.700 \\
0 \\
\end{array}$ & 0.496 & 0.6537 & dipakai \\
\hline 15 & $\begin{array}{l}0.600 \\
0 \\
\end{array}$ & 0.452 & 0.5731 & dipakai \\
\hline 16 & $\begin{array}{l}0.650 \\
0 \\
\end{array}$ & 0.234 & 0.3015 & gugur \\
\hline 17 & $\begin{array}{l}0.200 \\
0 \\
\end{array}$ & 0.544 & 0.7768 & gugur \\
\hline 18 & $\begin{array}{l}0.550 \\
0 \\
\end{array}$ & 0.331 & 0.4158 & dipakai \\
\hline 19 & $\begin{array}{l}0.850 \\
0 \\
\end{array}$ & 0.455 & 0.6975 & gugur \\
\hline 20 & $\begin{array}{l}0.500 \\
0\end{array}$ & 0.451 & 0.5648 & dipakai \\
\hline 21 & $\begin{array}{l}0.650 \\
0 \\
\end{array}$ & 0.481 & 0.6189 & dipakai \\
\hline 22 & $\begin{array}{l}0.700 \\
0 \\
\end{array}$ & 0.346 & 0.4564 & dipakai \\
\hline 23 & $\begin{array}{l}0.450 \\
0 \\
\end{array}$ & 0.555 & 0.6980 & dipakai \\
\hline 24 & $\begin{array}{l}0.150 \\
0 \\
\end{array}$ & 0.038 & 0.0588 & gugur \\
\hline 25 & $\begin{array}{l}0.600 \\
0\end{array}$ & 0.332 & 0.4209 & dipakai \\
\hline r11 & 0.865 & & & \\
\hline
\end{tabular}

Berdasarkan uji yang dilakukan pada setiap butir soal yaitu uji taraf kesukaran, validitas butir, daya beda dan reliabilitas maka dapat ditentukan soal yang dapat dipergunakan. Dari 25 butir soal yang dapat digunakan sebagai instrumen untuk menjaring data adalah 21 butir soal, sementara 4 butir soal masing-masing bernomor 16, 17, 19 dan 24 tidak dipakai untuk mengumpulkan data pretes-postes (Tabel 1).

Hasil pretes dan postes siswa kelas kontrol dapat dilihat seperti pada Tabel 2. Rata rata nilai pretes siswa 65,9 setelah dilakukan pembelajaran konvensional rata-rata nilai postes siswa meningkat menjadi 75,5 yang berarti terjadi peningkatan sebesar 9,6. Simpangan baku postes 18,05 yang berati variasi kemampuan siswa setelah dilakukan pembelajaran lebih baik dengan simpangan baku pretes 49,46. Hasil pretes dan postes siswa kelas Eksperimen dapat dilihat seperti pada Tabel 3. Rata rata nilai pretes siswa 62,1 setelah dilakukan perlakuan rata-rata nilai postes siswa meningkat menjadi 86,25 yang berati terjadi peningkatan sebesar 24,15. Simpangan baku postes 34,09 yang berati variasi kemampuan siswa setelah dilakukan pembelajaran konsisten dengan simpangan baku pretes 34,31 .

Tabel 2. Data Hasil Belajar Siswa Kelas Kontrol

\begin{tabular}{llll} 
Y & Statistik & Pretes & Postes \\
\hline Median & 66.0000 & 77.0000 \\
\hline Variance & 66.00 & 78.00 \\
\hline Std. Deviation & 49.463 & 18.053 \\
\hline Minimum & .512 & .512 \\
\hline Maximum & 50.00 & 68.00 \\
\hline Range & 74.00 & 82.00
\end{tabular}

Tabel 3. Data Hasil Belajar Siswa Kelas Eksperimen

\begin{tabular}{llll}
\hline $\mathbf{Y}$ & Statistik & Pretes & Postes \\
\hline $\begin{array}{l}\text { pre tes dan } \\
\text { pos tes }\end{array}$ & Mean & 62.1000 & 86.2500 \\
\hline & Median & 62.0000 & 88.0000 \\
& Variance & $60.00 \mathrm{a}$ & 88.00 \\
& Std. Deviation & 34.305 & 34.092 \\
& Minimum & .512 & .512 \\
& Maximum & 54.00 & 78.00 \\
& Range & 72.00 & 98.00 \\
\hline
\end{tabular}

Berikut ini adalah grafik histogram dari nilai postes kelas eksperimen dan kelas kontrol.

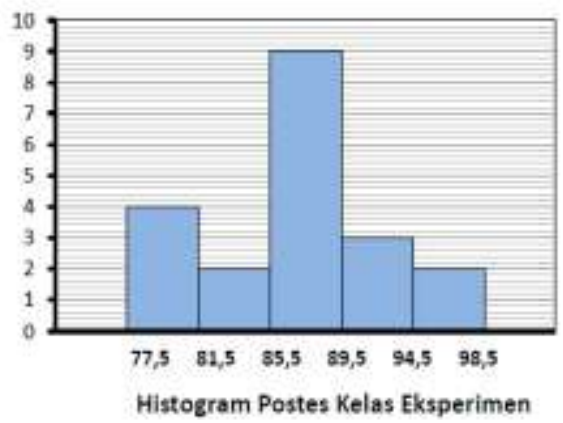

Gambar 1. Histogram postes kelas eksperimen

Dari data diatas dapat terlihat perbedaan antara kelas eksperimen dan kelas kontrol yang signifikan terhadap nilai pretes dan postest, dimana nilai pretes dan postes pada kelas eksperimen punya rentang perbedaan yang jauh dibanding pada kelas kontrol. Hal ini bisa dilihat pada garis pita biru untuk kelas eksperimen, dan pita hijau untuk kelas kontrol. 


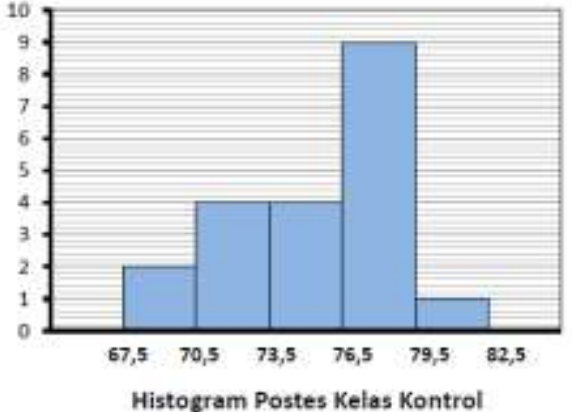

Gambar 2. Histogram postes kelas kontrol

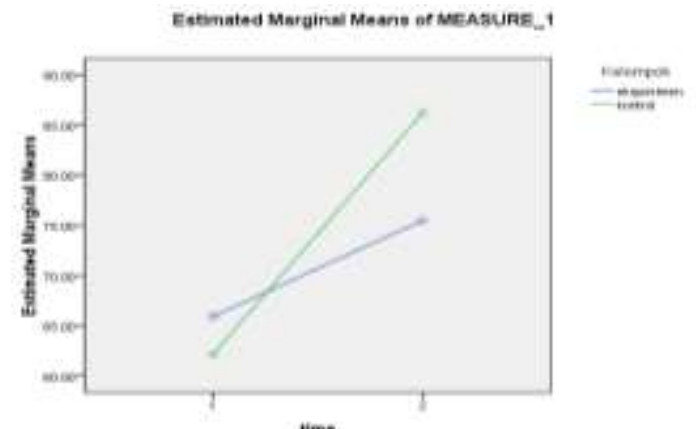

Gambar 3. Grafik perbedaan nilai pretes dan postes pada kelas kontrol dan eksperimen.

\section{KESIMPULAN}

Hasil belajar siswa menggunakan metoda pembelajaran outdoor lebih tinggi daripada yang tidak menggunakan metode tersebut. Hal ini terlihat dari nilai kelas eksperimen rata-ratanya $(80,75)$ lebih besar dari kelas kontrol $(64,00)$ dengan peningkatan sebesar 26,37\%.

Penggunaan metode pembelajaran outdoor pada materi konservasi sumberdaya alam perlu ditingkatkan lagi, karena dapat meningkatkan rasa ingin tahu siswa, keaktifan siswa dalam belajar dan memecahkan masalah serta dapat merangsang siswa untuk melakukan penyelidikan dan menemukan hal-hal baru dalam pembelajaran.

\section{DAFTAR PUSTAKA}

Alimah, S., \& Susilo, H. 2013. Desain Pembelajaran Biologi dengan Model Experiential Jelajah Alam Sekitar melalui
Lesson Study. In Proceeding Biology Education Conference: Biology, Science, Enviromental, and Learning (Vol. 10, No. 1).

Astuti, A. P., Ruyani, A., \& Wiryono, W. 2017. Respons Mahasiswa Terhadap Buku Panduan Dan Kegiatan Pelatihan "Teknik Monitoring Kura-Kura Cyclemys oldhamii". PENDIPA Journal of Science Education, 1(1).

Depdiknas, Perangkat Pembelajaran KTSP. 2002. Kurikulum Tingkat Satuan Pendidikan SMA (Sekolah Menengah Atas). Jakarta: Depdiknas.

Hastutiningsih, T., Prasetyo, A. P. B., \& Widiyaningrum, P. 2016. Pengembangan Panduan Pembelajaran Outdoor Bermuatan Karakter Peduli Lingkungan Pada Materi Ekologi. Journal of Innovative Science Education, 5(1), 28-35.

Indonesia, P. R., \& Indonesia, P. R. 1990. Undang Undang No. 5 Tahun 1990 Tentang: Konservasi Sumberdaya Alam Hayati Dan Ekosistemnya. Jakarta: Dephut.

Linawati, H. 2015. Pengaruh Metode Outdoor Study Terhadap Hasil Belajar Siswa Pada Konsep IPA Kelas IV Sekolah Dasar. Jurnal Penelitian Pendidikan Guru Sekolah Dasar, 3(2).

Mulyana, R. 2009. Penanaman etika lingkungan melalui sekolah perduli dan berbudaya lingkungan. Jurnal Tabularasa, 6(2), 175180.

Saputra, H. J., \& Novitasari, A. D. 2014. Keefektifan Pembelajaran Outdoor Learning Berbasis Nilai Karakter terhadap Hasil Belajar Tematik Terintegrasi Siswa Kelas IV SD Negeri 1 Meteseh Rembang. Malih Peddas (Majalah Ilmiah Pendidikan Dasar), 4(2). 